\title{
The Effectiveness Of Blended Learning Environments
}

\author{
Asst. Prof. Dr. Meltem Eryilmaz, Atilim University, Turkey
}

\begin{abstract}
The object of this experimental study is to measure the effectiveness of a blended learning environment which is laid out on the basis of features for face to face and online environments. The study was applied to 110 students who attend to Atilim University, Ankara, Turkey and take Introduction to Computers Course. During the application, students took the lesson face to face, online and blended. Blended learning environment has been designed in the form of online material sharing, forum, exam, text, picture and lesson summaries supported by videos. Following the training, a scale had been applied to the students on the effectiveness of blended learning environment. According to the results of the analysis, a significant difference between students' view in relation with blended learning environment as well as online and face to face learning environments. In their answers, students have expressed that they learn more effectively in a blended learning environment.
\end{abstract}

Keywords: Face to Face Learning; Online Learning; Blended Learning Environments

\section{INTRODUCTION}

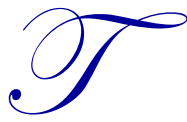

oday, rapid improvements at ICT (Information and Communication Technologies) as they affect every other area, they also influence and change the educational field. As a result of those changes, new approaches towards learning and teaching processes have come to the fore. Online, e-learning, m-learning, b-learning definitions are some of the expressions emerged in consequence of these approaches.

In various sources, b-learning can also be used as blended, mixed or hybrid (Driscoll, 2002; Jones, 2006; Laster, 2004; Oliver and Trigwell, 2005; Osguthorpe and Graham, 2003). When accessed in terms of information transfer and interaction methods b-learning is to combine the positive sides of online and conventional face to face learning methods (Finn and Bucceri, 2004). A face to face learning is one in which instructors and students meet together in the same place and at the same time. In the face to face learning, sessions are synchronous. While no communications technologies are required for a face to face session (Caner, 2012). According to the Frostburg State University's online learning definition, online learning can consist of both real-time interactions, such as in Collaborate, as well as interactions, which occur over extended periods of time, such as email or an online discussion board. Your courses will be broken up into modules that contain the learning content and activities you will have to complete. Each module usually begins with text readings, PowerPoint, and lectures that provide the information you will need to complete the assignments. The learning activities will vary each module and might include discussions, scenarios, simulations, projects, or papers.

Especially during the recent years, learning practices which have been implemented by blending, face to face and online methods together are often faced. In b-learning environment, students can access to learning materials by using web technologies outside the class while attending face to face education (Graham et al., 2003). Lessons can be supported by discussion groups, chat platforms and various content presentations. In this way advantageous and strong aspects of face to face and online learning complete each other (Thorne, 2003; Graham, 2006). While online learning environment enables time and location flexibility which is not possible within class environment, face to face education environment enables further social interaction. B-learning which combines the advantageous aspects of these two environments, have many pluses in terms of student, instructor and educational institution (Brown 2003; Singh and Reed, 2003). 
According to the researches, three main reasons why the blended learning is being recommended have been put forward (Graham, 2006):

a) Boosting up effectiveness of education.

b) Increased access and convenience.

c) Greater cost effectiveness.

Most often, educators adopt blended learning approaches to explore gains and tradeoffs in comparison with strictly traditional or entirely distributed environments (Graham et al., 2003).

Within the studies carried out, it is stated that in comparison to conventional face to face learning, students participating in b-learning applications take positive attitude towards lesson and internet supported learning and exam success rates are high (Dowling et al., 2003; O'Toole and Absalom, 2003; Riffell and Sibley, 2004). Furthermore, it is also stated that interaction in online environment supplies individual feedback and guidance. On the other hand, when b-learning is compared to face to face learning, there are also studies revealing that the difference between them are not so high in terms of success and attitude (Delialioglu \& Yildirim, 2008; Pereira et al., 2007). Including both face to face and online, b-learning has various advantageous such as flexibility in respect of location and time, online sharing of learning sources, interaction of students both inside and outside the classroom. Thanks to b-learning environments educators have more time to deal with students on one to one basis. B-learning is not only an online or massive open course (MOOCs). Within on-line learning, a student does not share as much time as in face to face education in class with the teacher. Students can have access to the course materials anytime.

However, such circumstance in which online learning enables individual learning, from time to time might cause students to feel isolated when students are together in a classroom discussing with an educator or other students in the same class, it may have positive influence on their motivations. MOOCs are also e-learning platforms intended for the masses. Through this model, open learning opportunity is provided for everyone who wishes to take lessons, without any limitation of attendance via a platform where they can not only see and hear but also participate and study together. In another words, since the "open source", namely the source in use, is open to everyone, online courses can be improved even more by the individual contributions of each participant. B-learning is the appropriate integration of the advantageous aspects of online and face to face learning methods during an education process. Table 1 categories the main distinctions between traditional academic and e-learning environments (Valiathan, 2008).

Table 1. Differences between face to face and online learning environment

\begin{tabular}{lcc}
\hline & Face to face Learning & Online Learning \\
\hline Focus of course & Group & Individual \\
Focus of content & Teacher-centered & Student-centered \\
Form & Synchronous & Asynchronous \\
Time & Scheduled & Anytime \\
Place & Classroom & Anywhere \\
Flexibility & Standardized & Customized \\
Content & Stable, durable & Dynamic, transitory \\
Number of students & Space delimited & Without limits \\
Instructor preparation & Some (transparencies) & Extensive pre-preparation \\
Distribution of materials & Hard copy & Electronic download \\
Interaction & Spontaneous & Structured \\
Range of interactivity & Full interactivity & Limited interactivity \\
\hline
\end{tabular}

Within an online classroom environment, students come and listen to the lesson and when they go home they do the homework and studies related to the lesson. In contrast, during b-learning, students have already got the information concerning the lesson before they come to the class. The advantageous aspect of this model is that it enables a student to reach a lot of sources regarding the lesson in advance before coming to the classroom. The educator uses the classroom for the purpose of creating an environment of discussion with students. The internet is a means of preparing a lesson. In a b-learning environment, the educator can prepare the videos and course materials 
related to the lesson and upload to a server beforehand. The students can reach all the materials regarding the subject to be studied before coming to the classroom and joining the activities related to the lesson. Thereafter, when they come to the classroom they can discuss the points that have not been understood with the educator or they can ask him to revise them again.

The educator can examine what the students have learnt and have them practice it when they are in the classroom. After the lesson, the student can learn effectively by combining the information previously obtained with the one clarified in the classroom. In the b-learning model, the educator plays the role of guide. The student is more active in comparison with face to face education. The other advantageous aspects of this model for students can be listed as follows:

a) The students have the control of the course videos.

b) The students can stop the lesson whenever they want and watch it again anytime.

c) The students can repeatedly watch the lesson within different timeframes.

d) The class activities and interaction with the educator enable the students to think in a more detailed manner and understand the topic better.

B-learning is not a key to success in education, of course. However, it is a means of providing quality and active education. When technological developments are considered, it is clearly seen that b-learning increases the quality of education and therefore in future it will be more preferable learning approach. The object of this study is to measure the effectiveness of a b-learning environment.

\section{Material, Techniques}

In this study, the students who took the lesson "Introduction to Computers" in a b-learning environment which is a combination of both face to face and online environments, were asked to evaluate the environments separately and it was aimed to measure the effectiveness of the blended learning environment in comparison with the other environments. The study was applied to the first grade students studying at the departments of the Faculty of Arts and Sciences at Atilim University in 2013 - 2014 academic year. The duration of the study was limited to fourteen weeks. Two weeks of these were exam weeks, four weeks were in the form of online, four weeks were face to face and remaining four weeks were blended education. An open source platform Moodle software was preferred for the student placement examination, which was required for the study. During the study, which was done with the participation of 110 students, at the end of fourteen weeks a scale whose analysis of acceptability and reliability was done beforehand and which was developed by Cabi and Gulbahar for measuring the effectiveness of blended learning environments. The students filled out the scales through the internet. The scale was composed of a structure with four factors which included 55 items in total. Accordingly, the factors were face to face learning environments, online learning environments, blended learning environments and technical issues. On the scale, the questions were asked under three different sections regarding face to face, online and blended learning environments. On the 5 point Likert type scale the numbers stand for some adverbs of frequency. That is, $1=$ Always, $2=$ Often, $3=$ Sometimes, $4=$ rarely and $5=$ Never. Since the scale results represent normal distribution, it was decided to use a parametric test. A t-test was used for dependent samplings at the state of analysis.

\section{Findings}

As a result of analysis, scale points were added up with item points and by dividing total point to the number of items. On the 5 point Likert type scale the numbers stand for some adverbs of frequency. According to the calculated average, points were rated as Always if it was 1.0-1.8; Often if it was 1.81-2.60; Sometimes if it was 2.61-3.40; rarely if it was 3.41-4.20 and Never if it was 4.21-5.0. According to the findings, the average of scale points regarding face to face learning environment of the students who participated the study have come out as (by $\bar{x}$ $=2.63$ means sometimes); scale points average regarding online learning settings have come out as (by $\bar{x}=2.67$ means sometimes) and scale points average regarding blended learning environment have come out as (by $\bar{x}=1.94$ means often). According to these results it can be interpreted as students' positive opinions for effectiveness of blended learning environments are higher than the other environments (Table 2). 
Table 2. Descriptive statistics for the environments

\begin{tabular}{lcc}
\hline & Average & $\begin{array}{c}\text { Standard } \\
\text { Deviation }\end{array}$ \\
\hline Face to Face & 2,63 & 0,89 \\
Online & 2,67 & 0,68 \\
Blended & 1,94 & 0,84 \\
\hline
\end{tabular}

For determination of whether there is a significant difference between students' opinion for face to face learning environment and online learning environment, it was analyzed with $t$ test for dependent samplings. According to the analysis results no significant difference could be found between students' opinion for online learning and face to face learning environments $(\mathrm{p}>0.05)$. The $0,605 \mathrm{R}$ value shows that there is a middle level positive relationship between students' opinion for online and face to face learning environments (Table 3 ).

Table 3. $\mathrm{t}$ test for the face to face and online learning environments

\begin{tabular}{lcc|ccc}
\hline & Average & $\begin{array}{c}\text { Standard } \\
\text { Deviation }\end{array}$ & $\mathbf{t}$ & $\mathbf{p}$ & $\mathbf{R}$ \\
\hline Face to Face & 2,43 & 0,89 & $-0,592$ & 0,555 & 0,605 \\
Online & 2,47 & 0,68 & & \\
\hline
\end{tabular}

For determination of whether there is a significant difference between students' opinion for face to face and blended learning environment, it was analyzed with $t$ test for dependent samplings. According to the analysis results a significant difference was found between students' opinion for blended learning and face to face learning environment $(\mathrm{p}<0.05)$. The $0,360 \mathrm{R}$ value shows that there is a poor level positive relationship between students' opinion for blended and face to face learning environments (Table 4).

Table 4. $t$ test for face to face learning environment and blended learning environments

\begin{tabular}{lcc|ccc} 
& Average & $\begin{array}{c}\text { Standard } \\
\text { Deviation }\end{array}$ & t & p & R \\
\hline Face to Face & 2,43 & 0,89 & 5,773 & $0,000^{*}$ & 0,360 \\
Blended & 1,94 & 0,84 & & \\
\hline
\end{tabular}

For determination of whether there is a significant difference between students' opinion for online and blended learning environment, it was analyzed with $t$ test for dependent samplings. According to the analysis results a significant difference was found between students' opinion for blended and online learning environment ( $\mathrm{p}<0.05)$. The $0,592 \mathrm{R}$ value shows that there is a middle level positive relationship between students' opinion for blended and online learning environments (Table 5).

Table 5. $\mathrm{t}$ test for online learning environment and blended learning environments

\begin{tabular}{|c|c|c|c|c|c|}
\hline & Average & $\begin{array}{c}\text { Standard } \\
\text { Deviation } \\
\end{array}$ & $\mathbf{t}$ & $\mathbf{p}$ & $\mathbf{R}$ \\
\hline $\begin{array}{l}\text { Online } \\
\text { Blended }\end{array}$ & $\begin{array}{l}2,47 \\
1,94 \\
\end{array}$ & $\begin{array}{l}0,68 \\
0,84 \\
\end{array}$ & 8,648 & $0,000 *$ & 0,592 \\
\hline
\end{tabular}




\section{CONCLUSIONS}

The study aimed to measure the effectiveness of blended learning environment which is laid out on the basis of features for face to face and online environments. The study was applied to 110 students who attend to Atilim University and take Introduction to Computers Course. Blended learning environment has been designed in the form of online material sharing, forum, exam, text, picture and video supported lesson summaries. Following the training, a scale had been applied to the students on the effectiveness of blended learning environment. Based on the study findings, the following discussion can be made:

Regardless of the types of b-learning, it was found to have a positive effect on learners' study achievement than the face to face learning environments. In b-learning environments, learners cooperate actively. This, as pointed out in previous studies on collaborative learning in an e-learning environment, means that learners acquire existing knowledge and actively create new knowledge for given task performance in the process of sharing knowledge with the peers (Insuk, Junghun, Eunmo, Seonghee, 2006). It is likely that the b-learning improved students' study achievement through cognitive activities. According to the analysis results it can reputed that opinions of the students who studied in blended environment are varying comparing other environments and blended learning environment is more effective than face to face and online learning environments. Furthermore, when in-class observations and student opinions are taken into consideration, it can be reputed that participants have positive opinions for internet supported applications and find blended learning useful. When assessing given answers there are opinions by the students for that blended learning environments provide positive effect on them and pose as an important experience for their future life. It can be declared that in the view of these statements educational practices designed within blended environments are beneficial to the students in terms of contentment, learning, attention and motivation.

\section{AUTHOR INFORMATION}

Asst. Prof. Dr. Meltem Eryilmaz. After graduating from METU Department of Statistics, Asst. Prof. Dr. Meltem Eryilmaz took MS degree from Computer Engineering Department of Atilim University. She took PhD degree from Department of Computer Education and Instructional Technology (CEIT), Ankara University. She still studies on distance education, e-learning, blended learning, flip classrom, flipped learning and adaptive learning at Computer Engineering department of Atilim University.

\section{REFERENCES}

Brown, R. (2003). Blending learning: Rich experiences from a rich picture. Training and Development in Australia, 30 (3), 14-17.

Cabi, E. and Gulbahar, Y. (2013). A scale development study for assessing the effectiveness of blended learning environments. Pegem Journal of Education \& Instruction, 3(3), 2013, 11-26.

Caner, M. (2012). The definition of blended learning in higher education. In P. Anastasiades (Ed.), Blended Learning Environments for Adults: Evaluations and Frameworks. Hershey, PA: IGI Global. doi:10.4018/978-1-4666-0939-6.ch002.

Delialioglu, O., Yildirim, Z. (2008), Design and Development of a Technology Enhanced Hybrid Instruction Based on MOLTA Model: It's Efectiveness in Comparison to Traditional Instruction. Computers \& Education 51 474-483

Dowling, C., Godfrey, J. M. and Gyles, N. (2003). Do hybrid flexible delivery teaching methods improve accounting students learning outcomes? Account. Educ. 12(4), 373-391.

Driscoll, M. (2002). Blended learning: let's get beyond the hype [electronic version]. e-Learning, 54.

Finn, A. and Bucceri, M. (2004). A case study approach to blended learning, retrieved January 15, 2008 from http://www.centra.com/download/whitepapers/CaseStudy_BlendedLearning.pdf.

Graham, C. R., Allen, S. and Ure, D. (2003). Blended learning environments: A review of the research literature. Unpublished manuscript, Provo, UT.Reasons, S. G. (2004).

Graham, C. R. (2006). Blended learning systems: definition, current trends, and future directions. In Handbook of Blended Learning: Global Perspectives Local Designs, edited by C. J. Bonk and C. R. Graham, pp. 3-21. SanFrancisco, CA: Pfeiffer Publishing. 
Insook L., Junghoon L., Eunmo S. and Sunghee J.(2006), A Study on the Development of Collaborative Learning Model and Behavioral Elements in e-Learning Environment, The Journal of Korean association of computer education, vol. 9, no. 2, (2006), pp. 27-36.

Jones, N. (2006). e-College Wales, a case study of blended learning. In Handbook of Blended Learning: Global Perspectives Local Designs, edited by C. J. Bonk and C. R. Graham, pp. 182-194. San Francisco, CA: Pfeiffer Publishing.

Laster, S. (2004). Blended learning: driving forward without a definition. In Engaging Communities: Wisdom from the Sloan Consortium, edited by J. C. Moore. Needham, MA: Sloan Consortium.

Oliver, M. and Trigwell, K. (2005). Can 'blended learning' be redeemed? E-learning 2(1), 17-26.

Osguthorpe, R. T. and Graham, C. R. (2003). Blended learning systems: definitions and directions. Q. Rev. Distance Educ. 4(3), 227-234

O'Toole, J. M. and Absalom, D. J. (2003). The impact of blended learning on student outcomes: is there room on the horse for two? J. Educ. Media 28(2-3), 179-190.

Pereira, J. A., Pleguezuelos, E., Mer1, A., Molina-Ros, A., Molina-Tomas, M. C., Masdeu, C. (2007), Effectiveness of Using Blended Learning Strategies For Teaching And Learning Human Anatomy. Medical Education 41: 189-195.

Riffell, S. K. and Sibley, D. F. (2004). Can hybrid course formats increase attendance in undergraduate environmental science courses? J. Nat. Resour. Life Sci. Educ., 33, 1-5.

Singh, H. and Reed, C. (2001). A white paper: Achieving success with blended learning, retrieved November, 2014 from http://www.leerbeleving.nl/wbts/wbt2014/blend-ce.pdf

Thorne, K. (2003). Blended learning: How to integrate online and traditional learning, London: Kogan Page. http://www.uady.mx/ contadur/seccip/articulos/libros online/ambientesvirt/KoganPage2003BlendedLearni ngHowtoIntegrateOnlineandTraditionalLearning2.pdf[Accessed: 10January 2015].

The University of Frostburg's Writing Center Web site http:/www.frostburg.edu/online/distancelearning/what-isonline-learning/[Accessed: 16 August 2015].

Valiathan P., Blended Learning Models [Internet]. Available at: [Accessed: 15 February 2015$].$ 